\title{
A COMPARISON OF EXTRACELLULAR PROTEASES FROM THREE PSYCHROTROPHIC STRAINS OF PSEUDOMONAS FLUORESCENS
}

\author{
ROSA MARGESIN AND FRANZ SCHINNER \\ Institute of Microbiology, University of Innsbruck, Technikerstraße 25, \\ A-6020 Innsbruck, Austria
}

(Received December 24, 1991)

\begin{abstract}
Extracellular proteases from three psychrotrophic strains of Pseudomonas fluorescens were purified and characterized. The cultivation temperature decisively influenced the excretion of protease into the medium. Highest enzyme production occurred at $10^{\circ} \mathrm{C}$ (one strain) or $20^{\circ} \mathrm{C}$ (two strains). The purified proteases showed a molecular weight between $47 \mathrm{kDa}$ and 51 $\mathrm{kDa}$, the $\mathrm{p} I$ values ranged from 7.8 to 7.4 . All three proteases were characterized by several closely focused bands. Sensitivity to metalchelating agents indicates that $P$. fluorescens proteases are metalloproteases (EC 3.4.24). The $\mathrm{pH}$ optimum for azocaseinolytic activity was at $\mathrm{pH}$ 67 , the temperature optimum was at $40-45^{\circ} \mathrm{C}$. The apparent energies of activation were $36.9-38.0 \mathrm{~kJ} \mathrm{~mol}^{-1}$. The proteases were thermolabile. By adding calcium ion an increasing thermostability was observed. SDS, urea and several metal ions inhibited proteolytic activities to different extents. Casein was the preferred substrate for the proteases. With casein concentrations up to $0.4-0.75 \%$ a Michaelis-Menten-type kinetics was observed, at higher casein concentrations a substrate inhibiton occurred. None of the proteases showed aminopeptidase activity.
\end{abstract}

Extremophile organisms have adapted to their environment in such a way that metabolic processes, reproduction and survival strategies are optimal in their natural biotopes. One factor that requires particularly high standards of adaption is the temperature. The environment of psychrophilic microorganisms from glacial areas is characterized by permanently cold temperatures, a constant change from freezing to thawing, as well as by permanently fluctuating substrate conditions. Psychrophilic organisms are able to grow and to multiply at $0^{\circ} \mathrm{C}$, and are thus adapted to these conditions. Obligate psychrophiles have an optimum growth

* Address reprint requests to: Dr. R. Margesin, Institute of Microbiology, University of Innsbruck, Technikerstraße 25, A-6020 Innsbruck, Austria. 
temperature at about $15^{\circ} \mathrm{C}$ or lower, whereas the optimum growth temperature of facultative psychrophiles (psychrotrophs) is higher than $15^{\circ} \mathrm{C}(1)$.

While mesophilic organisms form enzymes with temperature optima of around $60^{\circ} \mathrm{C}$, enzymes from psychrophiles are characterized by a low optimum temperature, a high activity at low temperatures, and a low activation energy (2-4). Therefore, enzymes from cold-adapted organisms could be useful for practical application (e.g., proteases for fining beer, leather industry, additives to detergents).

Psychrophilic microorganisms with proteolytic activities are ecologically highly important because they play an important role in the nitrogen cycle in cold biotopes. They gain further significance as spoilers of refrigerated food $(5,6)$. Most proteolytic psychrophilic microorganims have been isolated from soil $(7,8)$, aquatic environments $(7,9,10)$ and mainly from dairy products $(4,6,11-13)$, but little is known about this group of organisms from alpine and nival environments $(14,15)$.

The purpose of this work was the isolation and characterization of the proteases produced by three psychrotrophic $P$. fluorescens from alpine environment. By establishing the biochemical and the physicochemical properties of the enzymes we wanted to determine to what extent these properties were strain-specific or species-specific. The effect of temperature on growth and protease excretion was also investigated.

\section{MATERIALS AND METHODS}

Abbreviations. P., Pseudomonas; ACU, azocasein digestion unit; CU, casein digestion unit; Mes, morpholinoethane sulfonic acid; pNA, $p$-nitroanilides; PMSF, phenylmethylsulfonyl fluoride.

Chemicals. Azocasein, azoalbumin, casein $N, N$-dimethylated, bovine serum albumin, hemoglobin, ribonuclease, lysozyme, $p$-nitroanilides and the SDS molecular mass markers (SDS-6L) were from Sigma. Molecular mass markers for gel filtration were from Serva. Gel support film and Coomassie brilliant blue R250 were obtained from BioRad. S-Sepharose Fast Flow, Sephadex G-75, polyacrylamide gel plates for IEF and isoelectric focusing calibration kits were from Pharmacia LKB. Casein (Hammarsten), gelatine and Mes were obtained from Merck. Soybean meal and corn steep liqour were gifts from Biochemie Kundl (A). API 20 NE was obtained from API System, La Balmes les Grottes, France. All other chemicals were of analytical grade.

Organisms. The strains used throughout this work were isolated from cryoconite (black organic accumulations) of glaciers (strains 164/03 and 177/30) and soil materials (strain 165/14) in the European Alps at altitudes between 2,900 m and $4,000 \mathrm{~m}$. These strains were selected among 25 isolates as potent producers of protease. The characteristics of strains were determined microscopically, by gram-staining and by using API $20 \mathrm{NE}$ strips which were incubated at $10^{\circ} \mathrm{C}$ for 
$72 \mathrm{~h}$.

Cultivation. The strains were grown in the following medium: lactose, $2.5 \%$; glycerol, 2.5\%; corn steep liquor, $2 \%$; sodium caseinate, $1 \%$; soybean meal, $0.5 \%$; $\mathrm{CaCl}_{2} \cdot 2 \mathrm{H}_{2} \mathrm{O}, 0.1 \% ; \mathrm{MgSO}_{4} \cdot 7 \mathrm{H}_{2} \mathrm{O}, 0.1 \% ; \mathrm{KH}_{2} \mathrm{PO}_{4}, 0.025 \% ; \mathrm{Na}_{2} \mathrm{HPO}_{4} \cdot 12 \mathrm{H}_{2} \mathrm{O}$, $0.25 \%$; in distilled water. The $\mathrm{pH}$ of the medium was 6.9 . Cultures of $50 \mathrm{ml}$ in 500 $\mathrm{ml}$ flasks were inoculated with $1 \%$ of a subculture and were incubated at $10^{\circ} \mathrm{C}$ (strain $164 / 03$ ) or $20^{\circ} \mathrm{C}$ (strains $165 / 14$ and 177/30) on a rotary shaker with 180 rpm for $72 \mathrm{~h}$. Each culture was incubated in triplicate. For determining the effect of the temperature on growth and protease excretion, strains were incubated at 10 , 20 and $30^{\circ} \mathrm{C}$. Growth was monitored by measuring the optical density at $660 \mathrm{~nm}$.

Purification of proteases. All operations were carried out at $4{ }^{\circ} \mathrm{C}$. The cultures were centrifuged at $8,000 \mathrm{rpm}$ for $15 \mathrm{~min}$. The supernatant fluids of parallel cultures were pooled and $50 \mathrm{ml}$ were dialyzed against $2,000 \mathrm{ml}$ of $20 \mathrm{~mm}$ Mes$\mathrm{NaOH}$ buffer $\left(\mathrm{pH} 6.0\right.$ at $\left.4^{\circ} \mathrm{C}\right)$ for $15 \mathrm{~h}$. All aliquot $(25 \mathrm{ml})$ of the dialyzate was passed through an S-Sepharose Fast Flow column $(1 \times 10 \mathrm{~cm})$ which had been equilibrated with $20 \mathrm{~mm}$ Mes- $\mathrm{NaOH}$ buffer, $\mathrm{pH}$ 6.0. The adsorbed proteins were eluted with an increasing $\mathrm{NaCl}$ gradient $(0$ to $0.5 \mathrm{M})$ in the same buffer. The flow rate was $1 \mathrm{ml} \mathrm{min}^{-1}$; fractons of $5 \mathrm{ml}$ were collected. Fractions with the same specific activity were pooled, dialyzed against $1,000 \mathrm{ml}$ of $20 \mathrm{~mm}$ Mes- $\mathrm{NaOH}$ buffer (pH 6.7) for $4 \mathrm{~h}$, and stored at $-20^{\circ} \mathrm{C}$.

Electrophoresis. SDS-PAGE according to Laemmli (16) was performed with $1.5 \mathrm{~mm}$ gels with an acrylamide concentration of $12 \%$. Electrophoresis was carried out at $\mathrm{pH} 8.3$ at a constant voltage of $200 \mathrm{~V}$ for $40 \mathrm{~min}$. The gels were stained for 30 min with $0.1 \%$ Coomassie brilliant blue R250 dissolved in methanol-acetic acidwater $(40: 10: 50)$ and destained overnight in methanol-acetic acid-water $(40: 10$ : $50)$.

Isoelectric focusing was performed at $8^{\circ} \mathrm{C}$ and a $\mathrm{pH}$ gradient from 3.5 to 9.5 in thin-layer $(1 \mathrm{~mm})$ polyacrylamide gel plates. Samples were applied to the gels 30 $\mathrm{mm}$ from the anode. The gels were focused at $30 \mathrm{~W}, 1500 \mathrm{~V}, 50 \mathrm{~mA}$ with $585 \mathrm{Vh}$ (ca. $90 \mathrm{~min}$ ). A standard mixture of 12 proteins ( $\mathrm{pH} 3.5$ to 9.3 ) was used to indicate the $\mathrm{pH}$ gradient in the gel. Gels were fixed and stained as recommended by LKB instructions.

Dectection of proteases in IEF gels. A solution of $1 \%$ purified agar, $0.5 \%$ casein (Hammarsten) and $0.2 \% \mathrm{NaN}_{3}$ in $67 \mathrm{~mm}$ phosphate buffer, $\mathrm{pH} 7.0$, was boiled, cooled to $50^{\circ} \mathrm{C}$ and poured onto a gel support film $(100 \times 125 \mathrm{~mm})$. An IEF gel was applied to the casein gel; air bubbles were removed by gentle pressure. After an incubation period of $60 \mathrm{~min}$ at $30^{\circ} \mathrm{C}$ in a humid chamber the casein overlay was removed, rinsed with distilled water, fixed and stained as described for the IEF gels.

Determination of the molecular mass. The molecular mass of proteases was determined under native conditions by gel filtration and under denaturing conditions by SDS-PAGE.

Gel filtration according to Andrews (17) was performed at $4{ }^{\circ} \mathrm{C}$. A Sephadex G-75 column $(1.5 \times 50 \mathrm{~cm})$ was equilibrated with $67 \mathrm{~mm}$ phosphate buffer, $\mathrm{pH} 7.0$. 
The flow rate was $4.84 \mathrm{ml} \mathrm{h}^{-1} \mathrm{~cm}^{2}$, fractions of $1.43 \mathrm{ml}$ were collected. The void volume was determined with blue dextran 2000. Cytochrorne $c$ (12.3 kDa), myoglobin equine $(17.8 \mathrm{kDa})$, ovalbumin $(45 \mathrm{kDa})$ and bovine serum albumin $(67$ $\mathrm{kDa}$ ) were used for calibration.

For SDS-PAGE the protein standards lactalbumin $(14.2 \mathrm{kDa})$, trypsin inhibitor $(20.1 \mathrm{kDa})$, trypsinogen $(24 \mathrm{kDa})$, carbonic anhydrase $(29 \mathrm{kDa})$, glyceraldehyde-3-phosphate dehydrogenase $(36 \mathrm{kDa})$, ovalbumin $(45 \mathrm{kDa})$ and bovine serum albumin $(67 \mathrm{kDa})$ were used.

Protein determination. Protein concentration was measured as described by Bradford (18). Bovine serum albumin was used as standard. Protein content in gel filtration fractions was monitored by its absorbance at $280 \mathrm{~nm}$.

Protease assay. Proteolytic activity was measured by the digestion of azocasein (19). Enzyme solution $(50 \mu \mathrm{l})$ containing $0.002 \%$ protein was incubated with 300 $\mu \mathrm{l}$ of $1 \%$ azocasein in $67 \mathrm{~mm}$ phosphate buffer, $\mathrm{pH} 7.0$, at $30^{\circ} \mathrm{C}$ for $30 \mathrm{~min}$. The reaction was stopped by adding $1 \mathrm{ml}$ of $6 \%$ trichloroacetic acid. After a further 15 min the mixture was centrifuged and the absorbance of the supernatant was measured at $340 \mathrm{~nm}$. The activity was expressed in relative azocasein digestion units (ACU). One ACU was defined as the increase of 0.001 per min in absorbance under the described conditions. Specific activity was expressed in ACU per mg protein.

Aminopeptidase assay. L-Leucine-pNA, L-alanine-pNA, L-lysine-pNA, Lphenylalanine-pNA, L-glycine-pNA, L-arginine-pNA were dissolved in dimethylsulfoxide and diluted with $67 \mathrm{mM}$ phosphate buffer, $\mathrm{pH} 7.0$, to a concentration of 1.1 mM. For each assay, $600 \mu$ of substrate solution was mixed with $100 \mu$ l of enzyme soltuion and incubated at $30^{\circ} \mathrm{C}$ for $30 \mathrm{~min}$. The reaction was stopped on ice and the absorbance was measured at $410 \mathrm{~nm}$. One unit of aminopeptidase activity was expressed as $\mu \mathrm{mol}$ of $p$-nitroaniline formed per min.

Substrate specificity. Digestion of azoproteins (azocasein and azoalbumin) was measured with the standard protease assay.

Digestion of proteins was determined as previously described (19). Solutions (1\%) of casein, casein $N, N$-dimethylated, soybean meal, gelatine, bovine serum albumin, hemoglobin, lysozyme and ribonuclease were prepared in $67 \mathrm{~mm}$ phosphate buffer, $\mathrm{pH} 7.0$. Enzyme solution $(0.1 \mathrm{ml})$ containing $0.004 \%$ protein was incubated with $0.6 \mathrm{ml}$ of each of the preheated substrate solutions at $30^{\circ} \mathrm{C}$ for 30 min. The reaction was stopped by addition of $1 \mathrm{ml}$ of $7.5 \%$ trichloroacetic acid. After $30 \mathrm{~min}$ the mixtures were centrifuged and the absorbance of the supernatants was measured at $275 \mathrm{~nm}$. One casein digestion unit (CU) of the enzyme activity was expressed as $\mu \mathrm{mol}$ tyrosine liberated per min under the assay conditions.

Kinetics of casein utilization. Casein (Hammarsten) concentrations in the range from $0.05 \%$ to $1 \%$ were prepared in $67 \mathrm{~mm}$ phosphate buffer, $\mathrm{pH} 7.0$. Proteolytic activities of $0.004 \%$ protein solutions were measured with the method described in the section dealing with substrate specifity.

Effect of $\mathrm{pH}$ and temperature on activity and stability of proteases. These effects 
were determined using the standard protease assay with enzyme solutions containing $0.002 \%$ protein. Determination of the $\mathrm{pH}$ optimum was performed at $30^{\circ} \mathrm{C}$ with the following buffer systems (67 mM each): sodium acetate-acetic acid ( $\mathrm{pH} 5)$, $\mathrm{KH}_{2} \mathrm{PO}_{4}-\mathrm{Na}_{2} \mathrm{HPO}_{4}\left(\mathrm{pH} \mathrm{6-7)}, \mathrm{Na}_{2} \mathrm{~B}_{4} \mathrm{O}_{7}-\mathrm{HCl}(\mathrm{pH} 8-9), \mathrm{Na}_{2} \mathrm{~B}_{4} \mathrm{O}_{7}-\mathrm{NaOH}(\mathrm{pH} 10)\right.$, $\mathrm{Na}_{2} \mathrm{HPO}_{4}-\mathrm{NaOH}(\mathrm{pH} 11-12)$. The $\mathrm{pH}$ values were adjusted at $30^{\circ} \mathrm{C}$.

$\mathrm{pH}$ stability of the proteases was investigated in buffer solutions at various $\mathrm{pH}$ values. The following buffer systems were used $(67 \mathrm{mM}$ each): sodium acetateacetic acid ( $\mathrm{pH} 4-5), \mathrm{KH}_{2} \mathrm{PO}_{4}-\mathrm{Na}_{2} \mathrm{HPO}_{4}(\mathrm{pH}$ 6-8), glycine- $\mathrm{NaOH}$ (pH 9-10), $\mathrm{Na}_{2} \mathrm{HPO}_{4}-\mathrm{NaOH}$ (pH 11-12). Enzyme solutions (50 $\mu$ ) were incubated with 450 $\mu l$ of the buffer solutions at $20^{\circ} \mathrm{C}$ for $1 \mathrm{~h}$. After neutralization of the mixtures by adding $0.5 \mathrm{ml}$ of $200 \mathrm{~mm}$ phosphate buffer $\mathrm{pH} 7.0$, the residual activities were measured.

For determination of the temperature optimum the reaction was carried out at various temperatures and at $\mathrm{pH} 7.0$ for $30 \mathrm{~min}$.

For determination of the effect of temperature on enzyme stability the proteases were incubated at $\mathrm{pH} 7.0(67 \mathrm{mM}$ Tris- $\mathrm{HCl}$ buffer $)$ in the presence or absence of $10 \mathrm{mM} \mathrm{CaCl}_{2}$ at temperatures ranging from 0 to $60^{\circ} \mathrm{C}$ for $10 \mathrm{~min}$. In addition, the proteases were incubated at various temperatures for various periods. Afterwards the mixtures were rapidly cooled and the residual activities were determined.

Effect of various substances. The effect of several metal ions as well as of protease inhibitor was investigated. The proteases were also incubated with different concentrations of urea and SDS. For these experiments the enzymes $(0.002 \%$ protein $)$ were incubated with each of the reagents at $20^{\circ} \mathrm{C}$ and at $\mathrm{pH} 7.0$ for $1 \mathrm{~h}$. The residual activities were determined by the standard protease assay.

\section{RESULTS}

\section{Characterization of strains}

The strains were aerobic, gram-negative, motile, yellow-pigmented and rodshaped bacteria. They were oxidase-positive, arginine dihydrolase-positive and liquefied gelatine, but showed no activities of $\beta$-glucosidase, $\beta$-galactosidase and nitrate reductase. The strains hydrolyzed glucose, arabinose, mannose, mannitol, $\mathrm{N}$-acetyl glucosamine, gluconate, caprate, L-malate and citrate. Maltose, adipate and phenylacetate were not utilized. According to the APILAB computer programm (version 3.1) the strains were identified as $P$. fluorescens with a probability of $99 \%$. This result was confirmed by reference to Bergey's Manual of Systematic Bacteriology (20).

\section{Effect of temperature on growth and protease excretion}

Strain $164 / 03$ showed a similar cell density $\left(1 \times 10^{10}\right.$ cells per $\left.\mathrm{ml}\right)$ at all three cultivation temperatures, whereas strains $165 / 14$ and $177 / 30$ grew better at $10^{\circ} \mathrm{C}$ and $20^{\circ} \mathrm{C}$ than at $30^{\circ} \mathrm{C}$. The optimal growth temperature for strain $165 / 14$ was $10^{\circ} \mathrm{C}\left(2 \times 10^{10}\right.$ cells per $\left.\mathrm{ml}\right)$; strain $177 / 30$ grew equally well at $10^{\circ} \mathrm{C}$ and $20^{\circ} \mathrm{C}(2$ 
$\times 10^{10}$ cells per $\mathrm{ml}$ ). None of the strains formed protease at $30^{\circ} \mathrm{C}$. The strains $165 /$ 14 and $177 / 30$ formed a higher amount of protease at $20^{\circ} \mathrm{C}$ than at $10^{\circ} \mathrm{C}$, strain $164 /$ 03 exhibited the highest protease excretion at $10^{\circ} \mathrm{C}$. The highest proteolytic activities were observed in the stationary growth phase. Protease excretion still increased even after $72 \mathrm{~h}$. Growth and protease excretion at $10^{\circ} \mathrm{C}$ were delayed by $24 \mathrm{~h}$ in comparison to the ones at $20^{\circ} \mathrm{C}$.

\section{Purification of proteases}

The specific activity values of the dialyzates of protease-containing samples were $3.4 \times 10^{3}$ (sample $164 / 03$ ), $8.5 \times 10^{3}$ (sample $165 / 14$ ), and $6.7 \times 10^{3}$ (sample 177/30) ACU mg ${ }^{-1}$ protein. The proteases were eluted at $\mathrm{NaCl}$ concentrations of $0.15 \mathrm{M}$ (protease 165/14), $0.2 \mathrm{M}$ (protease 164/03) and $0.25 \mathrm{M}$ (protease 177/30) as single protein peaks. In each of the elution profiles the peak of protein coincided with the peak of protease activity (Fig. 1). Recoveries of $46 \%$ (protease 164/03), $51 \%$ (protease 165/14) and 75\% (protease 177/30) were obtained. The specific activities of the proteases were $21 \times 10^{3}, 39 \times 10^{3}$ and $38 \times 10^{3} \mathrm{ACU} \mathrm{mg}^{-1}$ protein respectively. The protein contents of the purified enzyme solutions were 266,334 and $293 \mu \mathrm{g} \mathrm{ml}^{-1}$ (Table 4).

\section{Homogeneity}

Each of the purified enzymes gave one single protein band on SDS-PAGE (Fig. 2). UV-absorption spectra showed a maximum absorbance at $275 \mathrm{~nm}$ and a minimum absorbance at $250 \mathrm{~nm}$.

\section{Molecular mass}

Estimations of molecular mass by gel filtration and by SDS-PAGE had the same results. Elution profiles of gel filtration showed one single protein peak coinciding with the peak of activity. The molecular mass of protease $164 / 03$ was 49 $\pm 2 \mathrm{kDa}$, the one of both the proteases $165 / 14$ and $177 / 30$ was $47 \pm 1 \mathrm{kDa}$ (Table 4). Determination by SDS-PAGE showed molecular masses of $50.6 \pm 0.5 \mathrm{kDa}$ (protease $164 / 03$ ), $48.6 \pm 1 \mathrm{kDa}$ (protease 165/14) and $49 \pm 1 \mathrm{kDa}$ (protease 177/30) respectively (Fig. 2, Table 4).

\section{Isoelectric point}

P. fluorescens proteases were characterized by several closely focused bands of proteins within a range of $\mathrm{p} I$ 7.5-6.8 (164/03), 7.9-7.5 (165/14) and 7.8-7.4 (177/ 30). The zymograms showed that in each case the protein bands in the IEF gels were associated with protease activity. The first $2-3$ bands close to the cathode with

Fig. 1. Chromatography profiles of three $P$. fluorescens proteases. $25 \mathrm{ml}$ of dialyzed culture supernatant were applied to an S-Sepharose Fast Flow column $(1 \times 10$ $\mathrm{cm})$. The adsorbed proteins were eluted with a linear $\mathrm{NaCl}$ gradient in $20 \mathrm{~mm}$ Mes- $\mathrm{NaOH}$ buffer, $\mathrm{pH} 6.0$, at a flow rate of $1 \mathrm{ml} \mathrm{min}^{-1}$. (O) Proteolytic activity toward azocasein; $(\triangle)$ protein content; dotted line, $\mathrm{NaCl}$ gradient (M). 

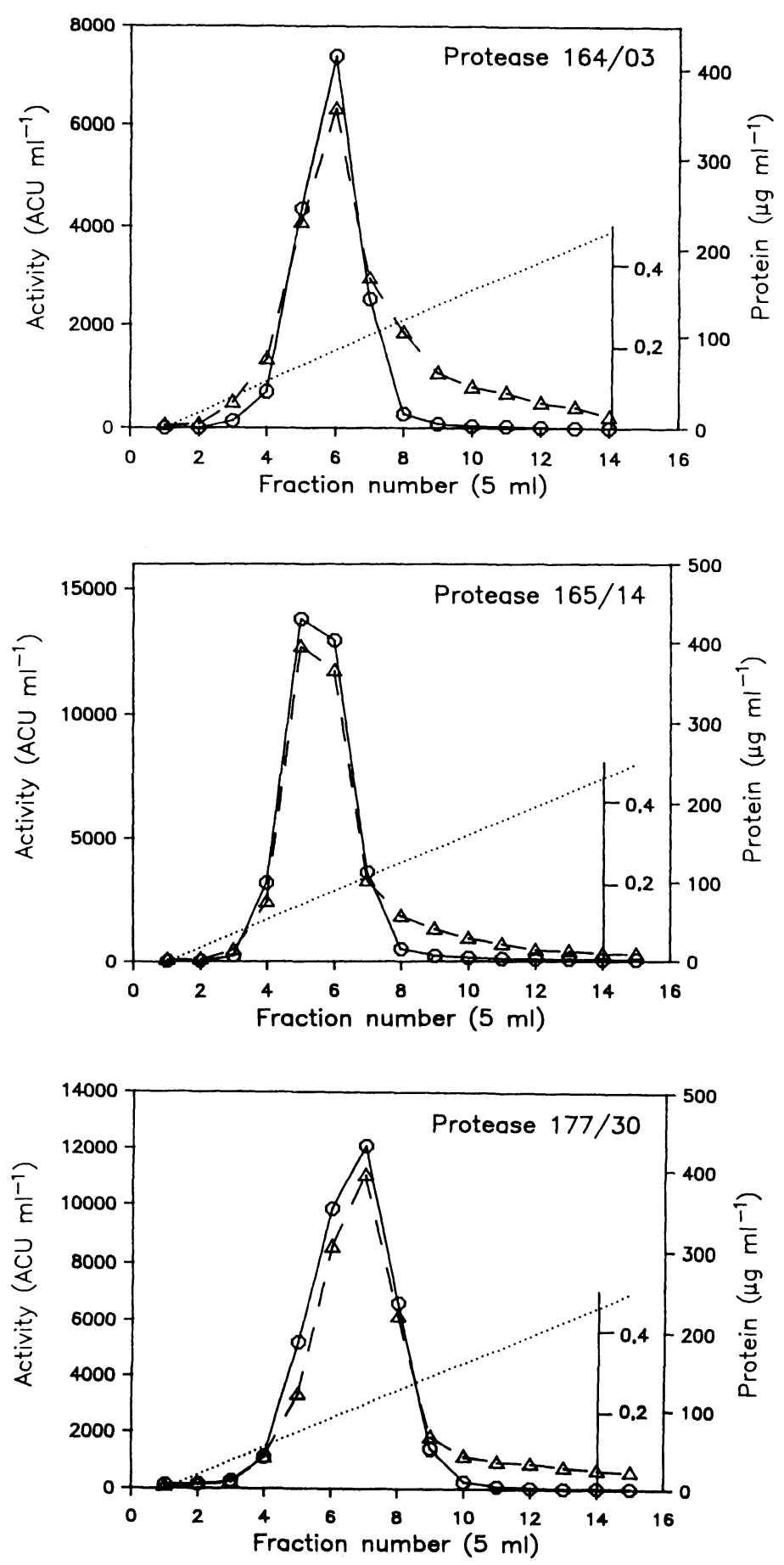


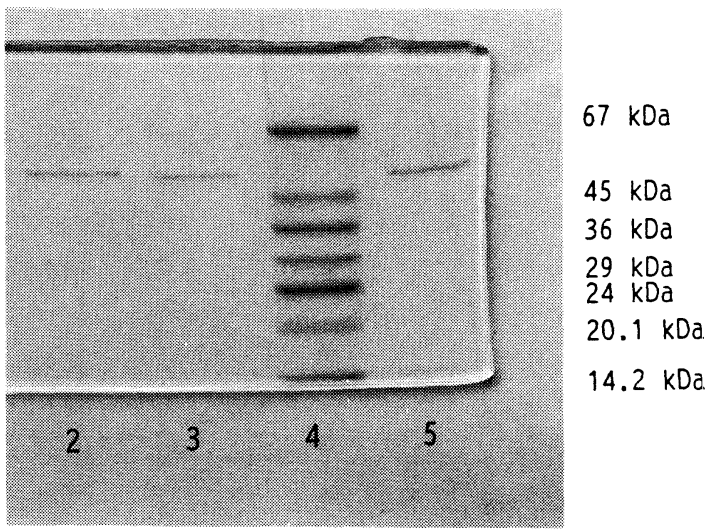

Fig. 2. SDS-PAGE of purified $P$. fluorescens proteases. (2), protease 164/03; (3), protease $165 / 14$; (5), protease $177 / 30$; (4), standard proteins: lactalbumin $(14.2$ $\mathrm{kDa})$, trypsin inhibitor $(20.1 \mathrm{kDa})$, trypsinogen $(24 \mathrm{kDa})$, carbonic anhydrase $(29$ $\mathrm{kDa})$, glyceraldehyde-3-phosphate dehydrogenase $(36 \mathrm{kDa})$, ovalbumin $(45 \mathrm{kDa})$, bovine serum albumin $(67 \mathrm{kDa})$.

pI's of 7.5-7.4 (protease 164/03), 7.8 (protease 165/14), 7.8-7.7 (protease 177/30) had as well the highest protein content as the highest activity in the zymograms; a further 3-6 bands were less developed.

\section{Effect of $p H$ on activity}

The proteases were found to have a neutral $\mathrm{pH}$ optimum. Enzymes 165/14 and $177 / 30$ showed more than $80 \%$ of their maximum activity within the $\mathrm{pH}$ range of 6 to 9 . Protease $164 / 03$ lost $75 \%$ of activity at $\mathrm{pH} 9$ and showed a higher activity at $\mathrm{pH}$. The proteases lost their activities at $\mathrm{pH} 11$ and 12 (Fig. 3).

\section{Effect of pH on stability}

Proteases $165 / 14$ and $177 / 30$ were stable from $\mathrm{pH} 4$ to 9 at $20^{\circ} \mathrm{C}$ for $1 \mathrm{~h}$, whereas protease $164 / 03$ was stable from $\mathrm{pH} 6$ to 9 . None of the proteases showed a residual activity at $\mathrm{pH} 11$ and 12 (Fig. 4).

\section{Effect of temperature on activity}

The proteases showed a maximum activity at $40-45^{\circ} \mathrm{C}$. At temperatures above the optimum temperature proteases rapidly lost activity. At $20^{\circ} \mathrm{C} 40 \%$ of activity could still be detected (Fig. 5).

The Arrhenius law was found to be followed between $20^{\circ} \mathrm{C}$ and $40^{\circ} \mathrm{C}$, and apparent activation energies in the range of $36.9-38.0 \mathrm{~kJ} \mathrm{~mol}^{-1}$ for the hydrolysis of azocasein were calculated (Table 4). These activation energies were much lower than the values obtained from proteases of mesophilic origin. Subtilisin Carlsberg (Sigma) and Savinase ${ }^{\mathrm{R}}$ (Novo) were tested under the same conditions and showed 


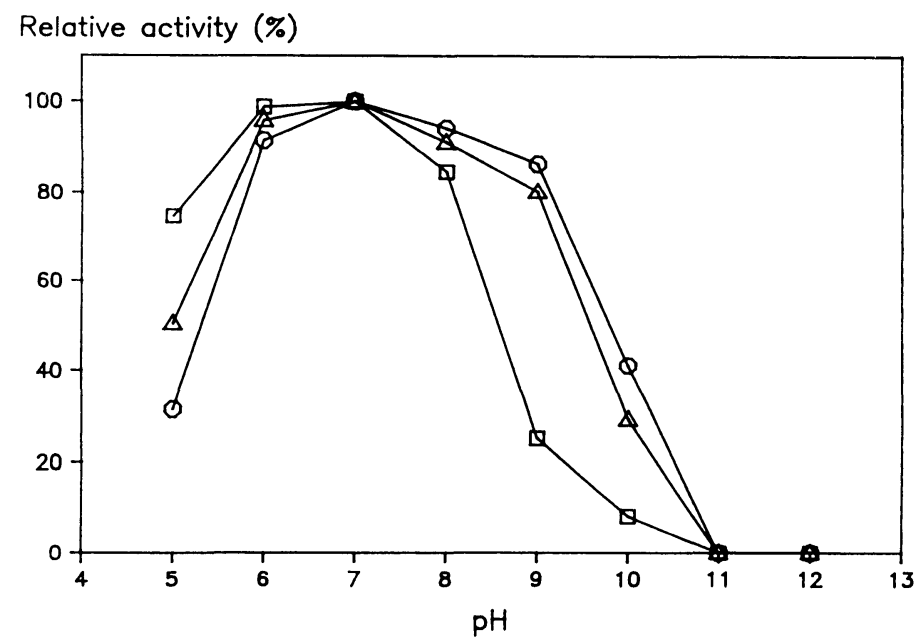

Fig. 3. Effect of $\mathrm{pH}$ on activity of proteases. The reaction was carried out with azocasein at $30^{\circ} \mathrm{C}$ for $30 \mathrm{~min}$. The buffer systems used (each $67 \mathrm{~mm}$ ) were: sodium acetate-acetic acid ( $\mathrm{pH} 5$ ), $\mathrm{KH}_{2} \mathrm{PO}_{4}-\mathrm{Na}_{2} \mathrm{HPO}_{4}$ ( $\mathrm{pH}$ 6-7), $\mathrm{Na}_{2} \mathrm{~B}_{4} \mathrm{O}_{7}-\mathrm{HCl}$ (pH 8-9), $\mathrm{Na}_{2} \mathrm{~B}_{4} \mathrm{O}_{7}-\mathrm{NaOH}(\mathrm{pH} \mathrm{10}), \mathrm{Na}_{2} \mathrm{HPO}_{4}-\mathrm{NaOH}(\mathrm{pH} \mathrm{11-12).} \mathrm{( \square )} \mathrm{protease} 164 / 03,(\bigcirc)$ protease $165 / 14,(\triangle)$ protease $177 / 30$.

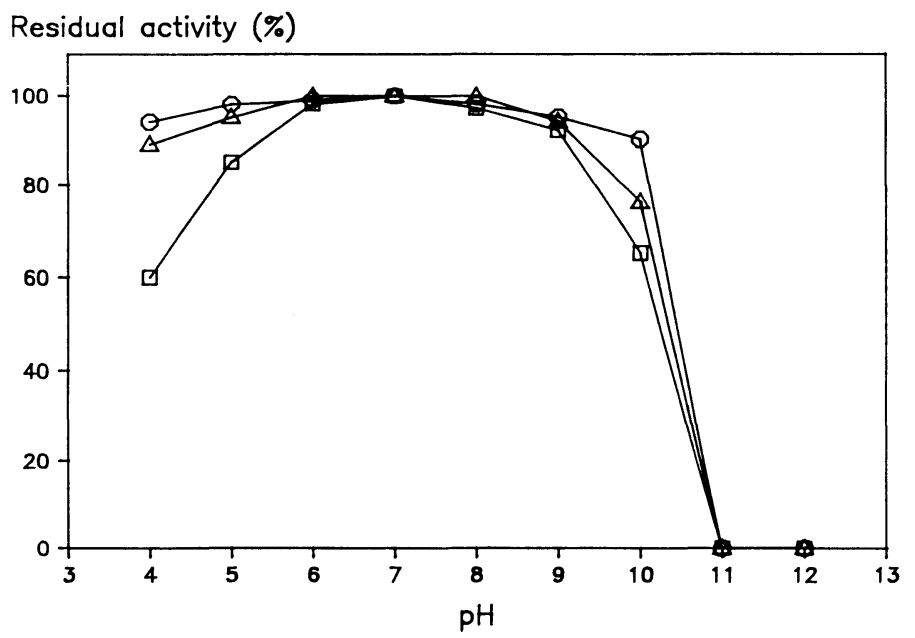

Fig. 4. Effect of $\mathrm{pH}$ on stability of proteases. Enzymes were incubated at $20^{\circ} \mathrm{C}$ for $1 \mathrm{~h}$ at varying $\mathrm{pH}$. The buffers $(67 \mathrm{~mm})$ were: sodium acetate-acetic acid $(\mathrm{pH} \mathrm{4-5)}$, $\mathrm{KH}_{2} \mathrm{PO}_{4}-\mathrm{Na}_{2} \mathrm{HPO}_{4}$ (pH 6-8), glycine- $\mathrm{NaOH}$ (pH 9-10), $\mathrm{Na}_{2} \mathrm{HPO}_{4}-\mathrm{NaOH}(\mathrm{pH} \mathrm{11-}$ 12). After incubation the $\mathrm{pH}$ of the enzyme solutions was adjusted to $\mathrm{pH} 7.0$ and the residual activities were determined at $30^{\circ} \mathrm{C}$ with azocasein. ( $\square$ ) protease $164 / 03,(\bigcirc)$ protease $165 / 14,(\triangle)$ protease $177 / 30$. 


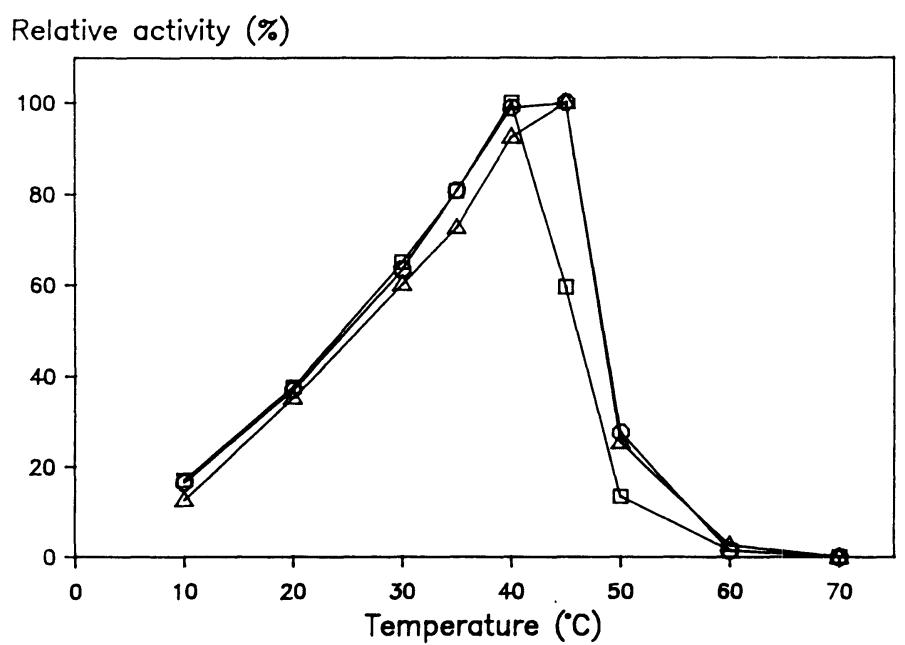

Fig. 5. Effect of temperature on activity of proteases. The reaction was carried out with azocasein at various temperatures and at $\mathrm{pH} 7.0$ for $30 \mathrm{~min} . \quad(\square)$ protease $164 / 03,(\bigcirc)$ protease $165 / 14,(\triangle)$ protease $177 / 30$.

activation energies of 59.1 and $62.2 \mathrm{~kJ} \mathrm{~mol}^{-1}$ respectively.

Effect of temperature on stability

All proteases were thermolabile. Among the enzymes, proteases 165/14 and $177 / 30$ were somewhat more stable than protease $164 / 03$. The activities of proteases were not affected after $1 \mathrm{~h}$ at $20^{\circ} \mathrm{C}$, whereas after $1 \mathrm{~h}$ at $30^{\circ} \mathrm{C}$ protease $164 / 03$ retained only $80 \%$ of activity. At $45^{\circ} \mathrm{C}$ and higher temperatures all three proteases were inactivated rapidly. By the addition of $10 \mathrm{~mm}$ calcium chloride the enzymes became more stable to temperature; the temperature inactivation profiles showed a shift of $5-10^{\circ} \mathrm{C}$. The effect of temperature on stability of protease $177 / 30$ is shown in Fig. 6.

\section{Effect of inhibitors}

Proteolytic activities of all three enzymes were not affected by sulfhydrylreagents (iodoacetamide) or serine-active reagents (PMSF). All proteases were completely inactivated by $1 \mathrm{~mm}$ EDTA. $o$-Phenanthroline inhibited protease 164/03 only slightly. Citrate and oxalate, known to be Ca-specific, affected none of the proteases. Proteases $165 / 14$ and $177 / 30$ differed only with regards to their reaction to 2,2-bipyridyl (Table 1). These results indicate that the enzymes are metalloproteases (EC 3.4.24). Regarding the stability against SDS and urea, protease 164/ 03 was most labile. Protease 165/14 showed the best stability against SDS, whereas protease $177 / 30$ was more stable against urea (Table 1). 


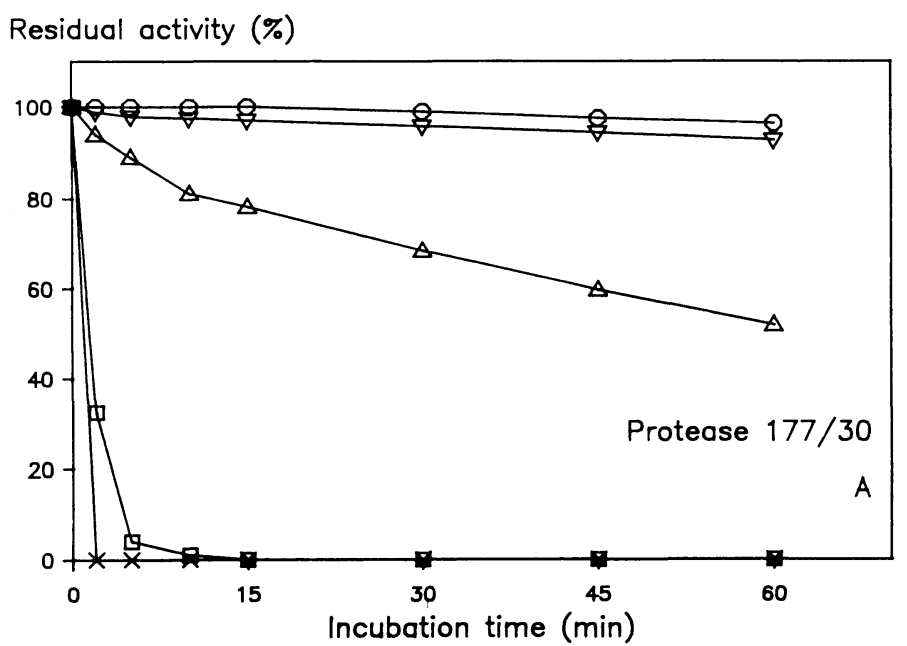

Residual activity (\%)

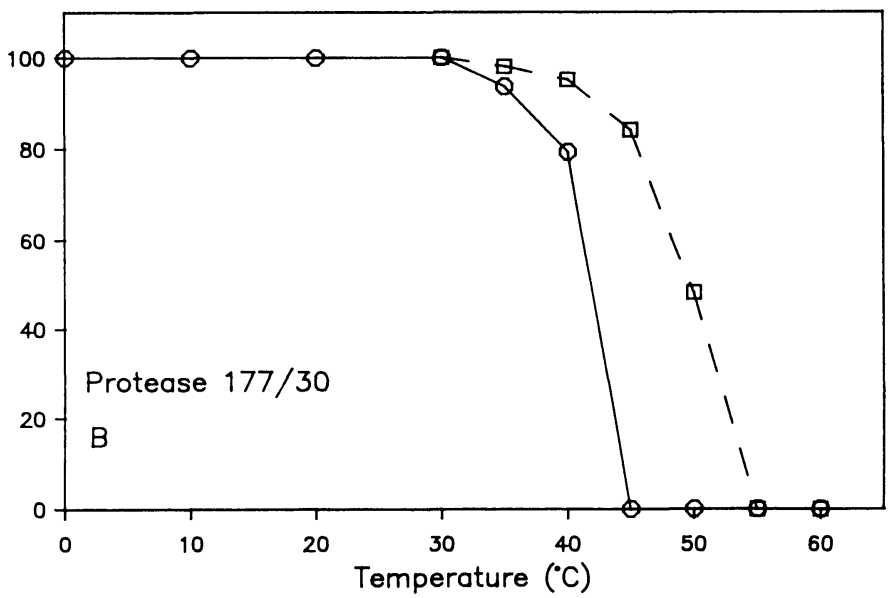

Fig. 6. Effect of temperature on stability of protease 177/30. A: The enzyme was incubated at $\mathrm{pH} 7.0$ and at $20^{\circ} \mathrm{C}(\bigcirc), 30^{\circ} \mathrm{C}(\nabla), 40^{\circ} \mathrm{C}(\triangle), 45^{\circ} \mathrm{C}(\square)$ and $50^{\circ} \mathrm{C}(\times)$ for the indicated periods. B: The enzyme was incubated at $\mathrm{pH} 7.0$ in the presence ( $\square$ ) or in the absence $(\bigcirc)$ of $10 \mathrm{mM} \mathrm{CaCl}_{2}$ at temperatures ranging from $0^{\circ} \mathrm{C}$ to $60^{\circ} \mathrm{C}$ for $10 \mathrm{~min}$. The residual activities were determined at $30^{\circ} \mathrm{C}$ and $\mathrm{pH} 7.0$.

\section{Effect of metal ions}

$\mathrm{Ag}^{+}, \mathrm{Cu}^{2+}, \mathrm{Hg}^{2+}$ and $\mathrm{Ni}^{2+}$ affected in decreasing order the activities of the proteases. $\mathrm{Fe}^{2+}, \mathrm{Mo}^{5+}, \mathrm{Co}^{2+}, \mathrm{Zn}^{2+}$ and $\mathrm{Pb}^{2+}$ on average reduced proteolytic activity by $10 \%$. The enzymes were unaffected by $\mathrm{Mg}^{2+}$ (Table 2). 
Table 1. Effect of inhibitors on activity of proteases. The enzymes were preincubated with each inhibitor at the stated concentration at $20^{\circ} \mathrm{C}$ and $\mathrm{pH} 7.0$ for $1 \mathrm{~h}$.

The residual activities were measured.

\begin{tabular}{|c|c|c|c|c|}
\hline \multirow{2}{*}{ Inhibitor } & \multirow{2}{*}{ Concentration } & \multicolumn{3}{|c|}{ Residual activity (\%) } \\
\hline & & $164 / 03$ & $165 / 14$ & $177 / 30$ \\
\hline None & & 100 & 100 & 100 \\
\hline Cysteine & $10 \mathrm{~mm}$ & 84 & 89 & 79 \\
\hline PMSF & $10 \mathrm{~mm}$ & 111 & 107 & 107 \\
\hline Iodoacetamide & $10 \mathrm{~mm}$ & 107 & 107 & 105 \\
\hline EDTA & $10 \mathrm{~mm}$ & 0 & 0 & 0 \\
\hline$o$-Phenanthroline & $10 \mathrm{~mm}$ & 93 & 57 & 80 \\
\hline $2,2^{\prime}$-Bipyridyl & $10 \mathrm{~mm}$ & 35 & 94 & 31 \\
\hline $\mathrm{KMnO}_{4}$ & $10 \mathrm{~mm}$ & 8 & 6 & 7 \\
\hline $\mathrm{KCN}$ & $10 \mathrm{~mm}$ & 87 & 100 & 100 \\
\hline Citrate & $100 \mathrm{~mm}$ & 101 & 100 & 97 \\
\hline Oxalate & $100 \mathrm{~mm}$ & 102 & 105 & 100 \\
\hline \multirow[t]{5}{*}{ SDS } & $0.025 \%$ & 4 & 99 & 57 \\
\hline & $0.050 \%$ & 0 & 82 & 40 \\
\hline & $0.100 \%$ & 0 & 47 & 4 \\
\hline & $0.250 \%$ & 0 & 6 & 0 \\
\hline & $0.500 \%$ & 0 & 0 & 0 \\
\hline \multirow[t]{4}{*}{ Urea } & $1 \mathrm{M}$ & 102 & 100 & 104 \\
\hline & $2 \mathrm{M}$ & 32 & 100 & 102 \\
\hline & $3 \mathrm{M}$ & 1 & 57 & 79 \\
\hline & $4 M$ & 0 & 0 & 0 \\
\hline
\end{tabular}

Table 2. Effect of metal ions on activity of proteases. The enzymes were preincubated with each metal ion ( $1 \mathrm{mM})$ at $20^{\circ} \mathrm{C}$ and $\mathrm{pH} 7.0$ for $1 \mathrm{~h}$.

The residual activities were measured.

\begin{tabular}{lccc}
\hline & \multicolumn{3}{c}{ Residual activity $(\%)$} \\
\cline { 2 - 4 } Salt & $164 / 03$ & $165 / 14$ & $177 / 30$ \\
\hline None & 100 & 100 & 100 \\
$\mathrm{AgNO}_{3}$ & 4 & 69 & 25 \\
$\mathrm{CuSO}_{4}$ & 13 & 41 & 25 \\
$\mathrm{HgSO}_{4}$ & 69 & 40 & 46 \\
$\mathrm{NiSO}_{4}$ & 69 & 79 & 79 \\
$\mathrm{FeSO}_{4}$ & 91 & 96 & 93 \\
$\mathrm{MoCl}_{5}$ & 90 & 96 & 93 \\
$\mathrm{CoSO}_{4}$ & 93 & 96 & 94 \\
$\mathrm{ZnSO}_{4}$ & 85 & 92 & 100 \\
$\mathrm{~Pb}$ & 97 & 101 & 95 \\
$\mathrm{MgSO}_{4}$ & 102 & 101 & 105 \\
\hline
\end{tabular}

\section{Substrate specificity}

The proteases preferred high molecular and denatured substrates like dimethylcasein and casein, whereas other proteins were hydrolyzed to a much lower extent. 
Table 3. Hydrolysis of proteins and azoproteins. The reactions were carried out at $30^{\circ} \mathrm{C}$ and $\mathrm{pH} 7$ for $30 \mathrm{~min}$. Data are presented as percentages of the rates of hydrolysis of dimethylcasein and azocasein respectively.

\begin{tabular}{lccc}
\hline \multirow{2}{*}{ Substrate (1\%) } & \multicolumn{3}{c}{ Rate of hydrolysis (\%) } \\
\cline { 2 - 4 } & $164 / 03$ & $165 / 14$ & $177 / 30$ \\
\hline Dimethylcasein & 100 & 100 & 100 \\
Casein & 89 & 88 & 80 \\
Soybean meal & 51 & 28 & 32 \\
Gelatine & 53 & 58 & 61 \\
Hemoglobin & 51 & 32 & 38 \\
Bovine serum albumin & 17 & 10 & 11 \\
Lysozyme & 26 & 14 & 17 \\
Ribonuclease & 0 & 0 & 0 \\
\hline Azocasein & 100 & 100 & 100 \\
Azoalbumin & 21 & 25 & 16 \\
\hline
\end{tabular}

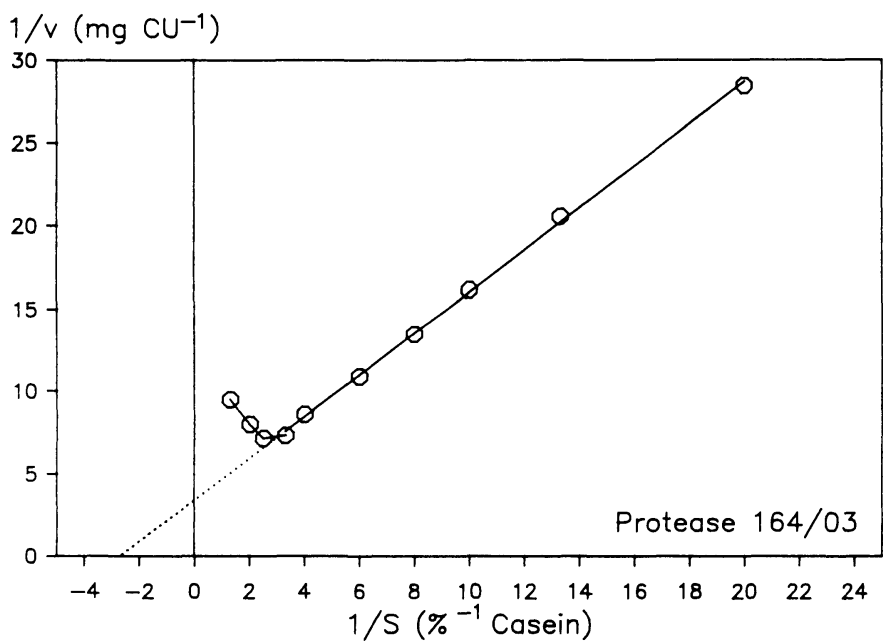

Fig. 7. Lineweaver-Burk plot for the hydrolysis of casein by protease $164 / 03$. The reaction was carried out with casein (Hammarsten), $\mathrm{pH} 7.0$, at $30^{\circ} \mathrm{C}$ for $30 \mathrm{~min}$. The dotted line is the extrapolation of the linear portion of the plot.

\section{Ribonuclease was not utilized (Table 3).}

\section{Kineties of casein utilization}

The rate of casein hydrolysis by the proteases was found to be proportional to casein concentrations up to $0.4 \%$ (protease 164/03) and $0.75 \%$ (proteases 165/14 and 177/30) respectively. There was a marked substrate inhibition at higher casein concentrations (Fig. 7). $K_{\mathrm{m}}$ and $V_{\max }$ values were obtained by extrapolation of the linear portion of the Lineweaver-Burk plots and are shown in Table 4. 
Table 4. Comparison of some properties of three $P$. fluorescens proteases.

\begin{tabular}{|c|c|c|c|}
\hline Property & $164 / 03$ & $165 / 14$ & $177 / 30$ \\
\hline Producer & P. fluorescens & P. fluorescens & P. fluorescens \\
\hline isolated from & cryoconite & soil & cryoconite \\
\hline at altitude (m) & 4,000 & 3,860 & 2,900 \\
\hline \multirow{2}{*}{ Cultivation } & $72 \mathrm{~h}$ & $72 \mathrm{~h}$ & $72 \mathrm{~h}$ \\
\hline & $10^{\circ} \mathrm{C}$ & $20^{\circ} \mathrm{C}$ & $20^{\circ} \mathrm{C}$ \\
\hline Production in culture $\left(\mathrm{ACU} \times 10^{3} \mathrm{ml}^{-1}\right)$ & 4.7 & 11.6 & 9.7 \\
\hline \multicolumn{4}{|l|}{ Purified proteases: } \\
\hline Recovery (\%) & 46 & 51 & 75 \\
\hline Specific activity $\left(\mathrm{ACU} \times 10^{3} \mathrm{mg}^{-1}\right.$ protein $)$ & 21.3 & 39.1 & 38.1 \\
\hline Mol wt, Sephadex G-75 (kDa) & 49 & 47 & 47 \\
\hline Mol wt, SDS-PAGE (kDa) & 50.6 & 48.6 & 49 \\
\hline Isoelectric point (main bands) & $7.5-7.4$ & 7.8 & $7.8-7.7$ \\
\hline Optimum pH & $6-7$ & 7 & 7 \\
\hline Optimum temperature $\left({ }^{\circ} \mathrm{C}\right)$ & 40 & $40-45$ & 45 \\
\hline Activation energy $\left(\mathrm{kJ} \mathrm{mol}^{-1}\right)$ & 37.5 & 38.0 & 36.9 \\
\hline $\mathrm{Ca}^{2+}$ stabilization & + & + & + \\
\hline$K_{\mathrm{m}}(\%$ casein $)$ & 0.39 & 0.57 & 0.39 \\
\hline$V_{\max }\left(\mathrm{CU} \mathrm{mg}{ }^{-1}\right.$ protein $)$ & 8.9 & 19.4 & 15.6 \\
\hline Classification by inhibitors & metalloprotease & metalloprotease & metalloprotease \\
\hline
\end{tabular}

\section{Aminopeptidase activity}

None of the proteases utilized any of the $p$-nitroanilides tested.

\section{DISCUSSION}

The proteases formed by three psychrotrophic strains of $P$. fluorescens were purified after dialysis directly via ion chromatography. We did not use an ammonium sulfate precipitation as this is well known for its high enzyme losses. From preliminary investigations (IEF) it was known that interfering proteins in culture supernatants had to be attributed mainly to nutrient components with a $\mathrm{p} I$ of 3.9-3.7. The homogeneity of the purified proteases was tested via SDS-PAGE, via IEF and via UV-absorption spectra and could be verified. As a consequence of the considerably lower activity in the culture fluid in comparison to the proteases $165 / 14$ and $177 / 30$, protease $164 / 03$ showed a low specific activity. Molecular mass of the proteases ranged from 49 to $51 \mathrm{kDa}$ when determined with SDS-PAGE; the values were lower by ca. $2 \mathrm{kDa}$ when determined with gel filtration. This close correspondence allows us to deduce that the proteases are monomers. Proteases from $P$. fluorescens are known to have a molecular mass of $35 \mathrm{kDa}(21), 38.4 \mathrm{kDa}$ (22), $45 \mathrm{kDa}(6)$ and $47 \mathrm{kDa}(13)$.

The results with IEF showed that all three purified proteases were characterized by several closely focused bands with decreasing concentrations of protein and activity respectively. As the $\mathrm{p} I$ values of the various bands showed only slight differences, we suppose that we are dealing with multiple forms of enzymes. 
Multiple bands may arise from post-transcriptional modifications of one protease or from starting self-digestion. A similar pattern was observed with proteases from Aeromonas (23). Depending on the biotype, different $\mathrm{p} I$ values of 8.3-8.2 (biotype I) and 7.25 (biotype III) were determined for proteases from psychrotrophic $P$. fluorescens (11).

The further characterization of the enzymes showed that the proteases $165 / 14$ and $177 / 30$ were more closely related, whereas protease $164 / 03$ exhibited various deviating properties.

The proteases belonged to the neutral proteases. With regards to the effect of pH on activity and stability, protease $164 / 03$ showed a more narrow pH-tolerance range than the other two proteases. Proteases from pseudomonads are known to have optimum activity at $\mathrm{pH} 6.5(22), 6.5-7.5(6), 7.2-7.4(12), 8(24)$, but also at $\mathrm{pH} 10(25)$. The $\mathrm{pH}$ stability of the investigated proteases ( $>85 \%$ residual activity after exposure to $\mathrm{pH} \mathrm{5-9}$ at $20^{\circ} \mathrm{C}$ ) was comparable to the one of a protease from a psychrotrophic Pseudomonas sp. (26).

Enzymes from psychrophiles and psychrotrophs differ from the ones from mesophiles mainly by their reaction to temperature. The excretion of enzymes seems to be more dependent on the low temperature than the growth of psychrophilic bacteria, thus reflecting the physiological adaptions to the extreme environments of the strains. For the formation of lipase (2) the same mechanisms were observed. The high excretion of protease in the stationary growth phase is thought to be controlled by nutritional conditions and catabolite repression.

Characteristics of the $P$. fluorescens proteases were temperature optima of 40$45^{\circ} \mathrm{C}$, high activities at $20^{\circ} \mathrm{C}$, low activation energies and asymmetrical slopes of the temperature profiles. An increase of $5^{\circ} \mathrm{C}$ above the optimum temperature caused a reduction of activity of $75 \%$, thus indicating thermal denaturation (27). For proteases from psychrotrophic pseudomonads, temperature optima of $30^{\circ} \mathrm{C}$ (10), $37^{\circ} \mathrm{C}(22,28), 40^{\circ} \mathrm{C}(12)$ and $45-50^{\circ} \mathrm{C}(10,13)$ were observed. Yet the temperature optimum can be influenced by the $\mathrm{pH}$ of the reaction (8). A low temperature optimum is the result of a high thermosensitivity. As the protease producers are never confroned with high temperatures in their natural environment, there is no necessity for high thermostability. In the process of evolution the adaption to low temperatures led to a development of genetically determined cold-stable proteins. Enzymes of cold-adapted organisms may show a flexible conformation allowing the reduction of the energy barrier, which may be responsible for their thermosensitivity. These enzymes have higher catalytic efficiencies than those of warm-adapted species (29).

The stabilizing effect of calcium has repeatedly been observed $(26,30)$. Metal ions such as calcium appear to be involved in the stabilization of the protein structure and are required for protection against heat inactivation (31).

Proteases formed by pseudomonads are mainly metalloproteases $(6,9,24,30$, 31). Metalloproteases are widespread and exhibit a broad substrate specifity. The investigated proteases preferred denatured and high molecular substrates such as 
casein and dimethylcasein. A comparable substrate specifity was determined with a protease from a psychrotrophic $P$. fluorescens (6). Yet the substrate utilization is dependent on the $\mathrm{pH}$ of the reaction (32). All three proteases showed a substrate inhibition from a certain casein concentration $(0.4-0.75 \%)$ onwards. A similar pattern has already been observed with a protease from $P$. fluorescens, for which a casein content of $0.5 \%$ proved to be inhibiting (22). Interactions between enzyme and substrate at positions removed from the active site could be responsible for the substrate inhibition. On the other side, an increasing casein aggregation at high casein concentrations may cause a decrease of substrate availability (22).

The investigated proteases were typical metalloproteases and showed the same general properties as those shown by other proteases of psychrotrophic $P$. fluorescens. The enzymes were well adapted for growth at low temperatures. The proteases produced by various strains of the same species were very similar with respect to their activities and specifities. Yet they could be differentiated, especially regarding their stability. The differences between proteases formed by various strains of one species are seen in connection with the respective genetic and physiological adaption of the strains, and with environmental and substrate conditions of the sites the strains orginated from.

This work was supported by Biochemie Kundl Ges.m.b.H./Austria. We thank Dr. B. Redl and Dr. N. Palma for helpful discussions.

\section{REFERENCES}

1) Morita, R. Y., Psychrophilic bacteria. Bacteriol. Rev., 39, 144-167 (1975).

2) Feller, G., Thiry, M., Arpigny, J. L., Mergeay, M., and Gerday, C., Lipases from psychrotrophic antarctic bacteria. FEMS Microbiol. Lett., 66, 239-244 (1990).

3) Genicot, S., Feller, G., and Gerday, Ch., Trypsin from antarctic fish (Paranotothania magellanica) as compared with trout (Salmo gairdneri) trypsin. Comp. Biochem. Physiol., 90B, 601-609 (1988).

4) Patel, T. R., Jackman, D. M., and Bartlett, F. M., Heat-stable protease from Pseudomonas fluorescens T16: Purification by affinity column chromatography and characterization. Appl. Environ. Microbiol., 46, 333-337 (1983).

5) Law, B. A., Reviews of the progress of dairy science: Enzymes of psychrotrophic bacteria and their effects on milk and milk products. J. Dairy Res., 46, 573-588 (1979).

6) Yan, L., Langlois, B. E., O'Leary, J., and Hicks, C. L., Purification and characterization of four extracellular proteases isolated from raw milk psychrotrophs. J. Dairy Sci., 68, 1323-1336 (1985).

7) Kato, N., Nagasawa, T., Tani, Y., and Ogata, K., Protease formation by a marine psychrophilic bacterium. Agric. Biol. Chem., 36, 1177-1184 (1972).

8) Nakajima, M., Mizusawa, K., and Yoshida, F., Purification and properties of an extracellular proteinase of psychrophilic Escherichia freundii. Eur. J. Biochem., 44, 87-96 (1974).

9) Juan, S. M. and Cazzulo, J. J., Production of extracellular protease by a freshwater psychrophilic bacterium. Rev. Assoc. Argent. Microbiol., 8, 8-13 (1976).

10) Kato, N., Nagasawa, T., Adachi, S., Tani, Y., and Ogata, K., Purification and properties of proteases from a marine-psychrophilic bacterium. Agric. Biol. Chem., 36, 1185-1192 (1972).

11) Diermayr, P., Zwerger, A., and Klostermeyer, H., Die proteolytisch aktiven psychrotrophen Bakterien in Rohmilch. 2. Differenzierung durch isoelektrische Fokussierung der Proteinasen. Milchwissenschaft, 40, 10-12 (1985). 
12) Patel, T. R., Bartlett, F. M., and Hamid, J., Extracellular heat-resistant proteases of psychrotrophic pseudomonads. J. Food Prot., 46, 90-94 (1983).

13) Richardson, B. C., The purification of a heat-stable protease from Pseudomonas fluorescens B52. N. Z. J. Dairy Sci. Technol., 16, 195-207 (1981).

14 Gounot, A. M., Effects of temperature on the growth of psychrophilic bacteria from glaciers. Can. J. Microbiol., 22, 839-846 (1976).

$15)$ Potier, P., Drevet, P., Gounot, A. M., and Hipkiss, A. R., Protein turnover in a psychrotrophic bacterium: proteolytic activity in extracts of cells grown at different temperatures. FEMS Microbiol. Lett., 44, 267-271 (1987).

16) Laemmli, U. K., Cleavage of structural proteins during the assembly of the head of bacteriophage T4. Nature, 227, 680-685 (1970).

17) Andrews, P., Estimation of the molecular weights of proteins by Sephadex gel-filtration. Biochem. J., 91, 222-233 (1964).

18) Bradford, M. M., A rapid and sensitive method for the quantitation of microgram quantities of protein utilizing the principle of protein-dye binding. Anal. Biochem., 72, 248-254 (1976).

19) Margesin, R. and Schinner, F., Characterization of a metalloprotease from psychrophilic Xanthomonas maltophilia. FEMS Microbiol. Lett., 79, 257-262 (1991).

20) Palleroni, N. Y., Family I. Pseudomonadaceae. In Bergey's Manual of Systematic Bacteriology, Vol. 1, ed. by Krieg, N. R. and Holt, J. G., Williams \& Wilkins, Baltimore (1984), p. 141-219.

21) Marshall, R. T. and Marstiller, J. K., Unique response to heat of extracellular protease of Pseudomonas fluorescens M5. J. Dairy Sci., 64, 1545-1550 (1981).

22) Alichanidis, E. and Andrews, A. T., Some properties of the extracellular protease produced by the psychrotrophic bacterium Pseudomonas fluorescens strain AR-11. Biochim. Biophys. Acta, 485, 424-433 (1977).

23 ) Nieto, T. P. and Ellis, A. E., Characterization of extracellular metallo- and serine-proteases of Aeromonas hydrophila strain B51. J. Gen. Microbiol., 132, 1975-1979 (1986).

24) Wretlind, B. and Wadström, T., Purification and properties of a protease with elastase activity from Pseudomonas aeruginosa. J. Gen. Microbiol., 103, 319-327 (1977).

25 ) Boethling, R. S., Purification and properties of a serine protease from Pseudomonas maltophila. J. Bacteriol., 121, 933-941 (1975).

26) Barach, J. T., Adams, D. M., and Speck, M. L., Stabilization of a psychrotrophic Pseudomonas protease by calcium against thermal inactivation in milk at ultrahigh temperature. Appl. Environ. Microbiol., 31, 875-879 (1976).

27) Ahlers, J., Arnold, A., von Döhren, Fr. R., and Peter, H. W., Enzymkinetik. Gustav Fischer, Stuttgart (1982), p. 149-152.

28) Yan, L., Langlois, B. E., O’Leary, J., and Hicks, C. L., Isolation, purification and partial characterization of four proteases from psychrotrophic bacteria from dairy origin. J. Dairy Sci., 65, 75 (Suppl. 1) (1982).

29) Hochachka, P. W. and Somero, G. N., Biochemical Adaption. Princeton University Press, Princeton, New Jersey (1984), p. 355-449.

30) Patel, T. R., Jackman, D. M., Williams, G. J., and Bartlett, F. M., Physicochemical properties of heat-stable proteases from psychrotrophic pseudomonads. J. Food Prot., 49, 183-188 (1986).

31) Patel, T. R. and Bartlett, F. M., Heat-stable proteases from psychrotrophic pseudomonads: Secondary structure and heat-stability. Food Microbiol., 5, 201-211 (1988).

32) Morihara, K., Pseudomonas aeruginosa protease. I. Purification and general properties. Biochim. Biophys. Acta, 73, 113-124 (1963). 